\title{
Activity-Based Approach In Social Workers' Professional Training
}

\section{Enfoque basado en actividades en la formación profesional de los trabajadores sociales}

\author{
Olena Chuiko \\ Taras Shevchenko National University of Kyiv, Kyiv, Ukraine \\ https://orcid.org/0000-0001-7088-0961 \\ Anastaciia Kuntsevska \\ Taras Shevchenko National University of Kyiv, Kyiv, Ukraine \\ https://orcid.org/0000-0002-0456-6234 \\ Anastasiia Holotenko \\ Taras Shevchenko National University of Kyiv, Kyiv, Ukraine \\ https://orcid.org/0000-0002-0261-4132

\section{Dong Jiahang} \\ Taras Shevchenko National University of Kyiv, Kyiv, Ukraine \\ https://orcid.org/0000-0002-9199-3970
}

*Correspondencia

Email: rkhosrorad@yahoo.com 


\section{Summary}

Social work education in Ukraine has changed dramatically over the last decades. It has a strong connection with the evolution of social work education as a field of professional practice. Recent changes in Ukrainian social policy, in particular the implementation of professional education requirements, based on the competency-oriented approach, the implementation of professional standards for social workers, the distinction of social work in a separate field of science and the complexity of social practice require the creation of unified training curriculum that corresponds to social needs and practice requirements. Creating a meaningful learning environment and raising awareness of professional objectives would be achievable by applying an activity-oriented approach to the professional education of social workers. This means that knowledge could never be isolated from activity. Activity-oriented educational practices contain the core components of professional activities and concern different aspects of social work. Profession-oriented practice includes general (volunteer activities, research, social project design, organizational and management) and additional (communicative, play and game, teamwork) forms and technologies, which demand from students to accumulate their experience in obtaining the essential forms of professional activities. Professional practice encompasses a set of principles, based on the prioritization of the social work profession, individual activity, participation and reflection, which make possible the development of the student's personal maturity and independence.

Keywords: Activity-Oriented Approach, Professional Education Of Social Workers, Professional-Oriented Practices, Groups Of Competencies, University Teacher.

\section{Resumen}

La educación en trabajo social en Ucrania ha cambiado drásticamente en las últimas décadas. Tiene una fuerte conexión con la evolución de la educación en trabajo social como campo de práctica profesional. Cambios recientes en la política social de Ucrania, en particular la implementación de los requisitos de educación profesional, basados en el enfoque orientado a las competencias, la implementación de estándares profesionales para los trabajadores sociales, la distinción del trabajo social en un campo separado de la ciencia y la complejidad de la práctica social requieren la creación de un plan de estudios de formación unificado que corresponda a las necesidades sociales y los requisitos de la práctica

La creación de un entorno de aprendizaje significativo y la sensibilización sobre los objetivos profesionales se podrían lograr aplicando un enfoque orientado a las actividades a la educación profesional de los trabajadores sociales. Esto significa que el conocimiento nunca podría aislarse de la actividad. Las prácticas educativas orientadas a la actividad contienen los componentes centrales de las actividades profesionales y se refieren a diferentes aspectos del trabajo social. La práctica profesional incluye formas y tecnologías generales (actividades de voluntariado, investigación, diseño de proyectos sociales, organización y gestión) y adicionales (comunicativas, lúdicas y de juego, trabajo en equipo), que exigen de los estudiantes acumular su experiencia en la obtención de las formas esenciales de formación profesional ocupaciones. La práctica profesional engloba un conjunto de principios, basados en la priorización de la profesión de trabajo social, la actividad individual, la participación y la reflexión, que posibilitan el desarrollo de la madurez e independencia personal del alumno.

Palabras clave: Enfoque Orientado a la Actividad, Formación Profesional de Trabajadores Sociales, Prácticas Orientadas al Profesional, Grupos de Competencias, Docente Universitario.

\section{Introduction}

Social workers' education in Ukraine had become a matter of intense debate only in the early 1990s. The main consequence of this interest was that social work emerged, triggered by powerful social changes, and shaped as an independent field of practice in post-Soviet 
Ukrainian space. Due to training social work professionals specialized university departments were established throughout Ukraine: Kyiv-Mohyla Academy in 1993; Uzhgorod National University in 1996; Lviv Polytechnic National University in 1999; Taras Shevchenko National University of Kyiv in 1999 and others.

Ultimately, the question arose about the nature of social workers` professional training and about the kind of educational models (especially foreign ones) should be used by pedagogical teams. The complexity of these processes has deepened due to the lack of educational standards in Ukraine.

Consequently, each department in Ukrainian universities had formed their "own concept" of social work education. The review of scientific publications in the professional community makes it possible to identify between some of the concepts and strategies that have become the guiding principles in the educational practice of training social workers in Ukraine from 1993 to the present.

In particular, Lukashevich M., Semigina T., Cherepanova G. (2007) have developed the idea of a person-centered model of social work education. In their perspective, the environment in which students are educated and taught should be a kind of laboratory of humanism, humaneness, creativity, ' to nurture the individuality and uniqueness of the social worker's personality, which become the foundation of their free individual style of work' (Lukashevich, Semigina, Cherepanova, 2007, p. 17).

The concept of a competency-based approach to professional training developed in particular by Y. Schwalb (2010) becoming popular. He stresses that this perspective "predicts a dramatic change" for existing pedagogical system and defines competence as "an ability of the individual to solve a certain category of tasks" (Schwalb, 2010, p. 31).

L. Mishchyk (2015) suggests to follow a systematic approach to the training of social workers, as "the methodological foundation of purposeful, coordinated actions will provide the necessary changes "in the family, in the group and in society" (Mishchyk, 2015, p. 154).

Furthermore, other approaches to professional education of social workers were presented, including reflexive (Vasilyeva, 2011), praxeological (Savitskaya, 2015), cultural (Ryabova, 2016).

Examining the state of education of social workers in Ukraine, I. Savelchuk (2016), shows that educational models have been developed in several stages - propedeutic (19902000), integrative (2000-2010), creative (2010 to the present) and the shift in phases has been determined by external and internal factors that make social work an area of social practice in Ukraine.

Such a variety of methods and paradigms in educational practice, on the one hand, confirms the concept of education that "shapes not a human in general but an individual in this society and for that society" (Mannheim, 2000), since it provides a choice of many similar things.

Comparing Ukrainian educational programs for social workers with similar international programs (USA, UK, France), researcher S. Kubitsky (2017) points out that Ukrainian education programs are not practical-oriented; only $10 \%$ of the entire learning time is dedicated to practice, which is not enough to train competences (Kubitsky, 2017, p. 22).

Most of Ukrainian universities are still susceptible to conventional pedagogy standards, to which education essentially considered as a one-sided process of passing theoretical knowledge from teachers to students, where learners alone are responsible for mastering the 
material. Feedback in the educational process is most often limited to the reproduction of the texts offered (lectures, textbooks, suggested literature), and evaluation of the knowledge reproduction level. Therefore, at the end of the study, the student has, at best, obtain knowledge and a general image of the profession. Furthermore, due to increasing demands and requirements of social practice toward specialists, the graduate student finds it impossible to entering professional practice.

Meanwhile, recent changes in Ukrainian social policy, in particular the implementation of professional education requirements for all levels (based on the competency-oriented approach), the implementation of professional standards for social workers, the distinction of social work in a separate field of science ( 23 Social work) require the creation of unified training curriculum that corresponds to social needs and practice requirements.

\section{Research methodology}

The purpose of this article is to expose the substance of the Activity paradigm in higher education and possibilities of implementing activity-based model in social workers professional learning.

In order to provide an adequate context for the model, a variety of tasks are highlighted: i) basic principles of Activity theory and its application to learning processes; ii) social work professional activity structure as a matter of education; iii) professional performance incorporation into the system of university professional training; iv) defining principles and main types of professional-oriented activities.

\section{Theoretical background}

Activity theory is one of the fundamental concepts of classical social philosophy, which focuses on a clash of individual and objective features of reality within the act of goal setting.

Activity theory and interdisciplinary analysis have resulted in a fruitful mix that is well balanced between theoretical concern and applied methodology. A line of theoretical development related to educational practices begins with Vygotsky, suggesting Zone of Proximal Development as a basic concept for understanding teaching and learning plus development of higher mental functions (Gedera, Williams, 2016). Psychological issues of the activity-based approach have been intensely developed by A.N. Leontyev (1977, 1983), pedagogical psychologists V.V. Davydov (1983), P.I. Galperin (1976), N. Chapaev, O. Akimova, A. Selivanov, T. Shaforostova, (2016), V.V. Rubtsov (2008).

Activity-based research theory creates and applies a methodology of its own, which is understood as a bridge between theory and data. In other words, methodology is more than a set of particular methods and techniques. This introduces and implements a theoretically driven set of principles, or "argumentative grammar" (Yamazumi, 2006).

Vygotsky's theoretical research inspired scientists not only on post-Soviet Union countries, but all over the world (Engeström, Martin, Peim; Bakhurst, Nardi). His idea of socialcultural development was expanded by the Finnish scholar Engeström, who introduced social and contextual dimensions to Vygotsky's model and broadened the mechanism by connecting the idea of activity systems to the definition of meaning, claiming that contexts are activity systems (Hansson, 2014).

Engeström particularly focused his attention on "contradictory objects in specific activities calls for new types of agency", regarding the creation of new activity as a method of reflective re-mediation, which could "open up associate degree entirely new question and result in the formation of a brand new object and a brand new activity" (Engestrom, 1999). 
The basic components of the activity structure are the subjects, the objects, the mediated instruments, the rules the communities and the division of labor. Subjects are individuals or groups of individuals who share the practices of mediating devices. Objects are the motives that are concealed in the involvement of the participant in the activity. The subject and the object in turn interact, characterizing both the human activity that takes shape and form from the motive's complex effect.

Activity Theory considers two major functions: i) internalization, which is closely connected with the replication of experience and, in particular, with the learning and socialization of students during the activity cycle; and ii) externalization which is considered the carrier of new instruments that transform the wider culture and models of the activities through the use of distinctive innovations and provision of strategic solutions (Mitsi, Papaspyrou, 2017).

The theory of activity focuses on how tradition, history and social interaction affect individual consciousness and collective activity organization. It is concerned with conceiving of human mental functioning and action in ways that go beyond the traditional psychological focus on the individual as the analytic unit (Engestrom, 2001).

As shown in Fig. 1, the structure of activity includes two types of activity - subjective (goal-setting subject) and objective (subject, tool and a product of activity). In the context of objective activity communications considered as the transformation of an object of activity into its product.

Figure (1): Activity structure

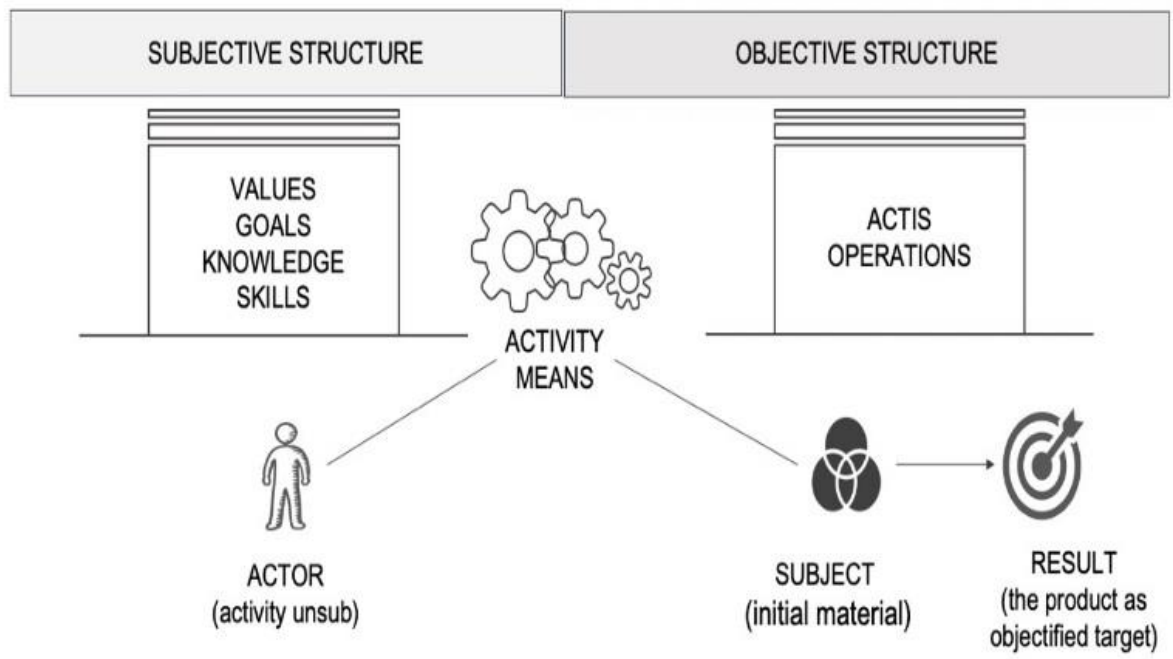

The concept of "subject" (an actor who performs activity) is the most important structural element of activity. Accordingly, subject performs several functions:

i) assessment of the situation components based on their significance: whether a particular environmental object could fulfill the function of means of future action or ancillary conditions of activity;

ii) identification of the personal meaning of objects, so their ability to meet the actor's initial needs (Bazhanov, 2009).

Activity-based education regards the learning process as a process of learning activities, which implies subject-oriented practical and mental actions. An act of activity, as well as 
particular action, always has a deliberate purpose, motivational conditioning and directed at tangible or intangible subject, and commonly has a certain psychological structure.

The act in its turn, whether it is practical, material or mental, is always mediated by various means, like a devise or a symbol. To teach activities means to encourage individual learning, independent goal-setting, finding different ways and means of operation organizing. What we call "knowledge" concerned as indicative basis of educational, and then extracurricular activity; "skills" are the matter of student's ability to carry out the "technological" side of learning.

Activity-based approach considers education and educational processes as an activity; which assumes that educator has a task during the teaching process to develop other forms of behavior, including cognitive ones. Such an educational approach does not exclude thought, memory and other processes, but only entails a different perception of their essence, specific role and sources (Maksakov, 2016). Although the substance of the "here and now" learning process are knowledge transferring or skills training, we have to acknowledge the fact, that they are "incorporated" in activity learning.

Activity-based learning-theoretical framework is one of the most common principles of human interactive learning activity, which goes beyond the conventional theory of learning rooted in individualistic behaviorism. This style of learning produces culturally new activity patterns that do not yet exist; and aimed on understanding and then breaking through the inner inconsistencies within and between their activity systems; it is learning that is used to understand their own lives and future (Yamazumi, 2006).

The activity-based approach demands an entirely new approach to the relation through knowledge and skills. Knowledge must not be contrasted against skills; however, its position has to be considered as their part: "Thus, we don't need "spare" knowledge, which is nonfunctional and cannot be used by students during their learning and practical training" (Leontiev, 2001). Learning means also carrying out certain operations or activities relevant to the knowledge, and knowledge is always concerned as relative phenomenon.

Understanding and applying knowledge also seems impossible without specific actions - the criterion of knowledge could never be isolated from activities.

Applying Activity approach to the learning process means that we should always reflect different aspects of all involved actors (Fig. 2).

Figure (2): The positional structure of the student and teacher interaction 


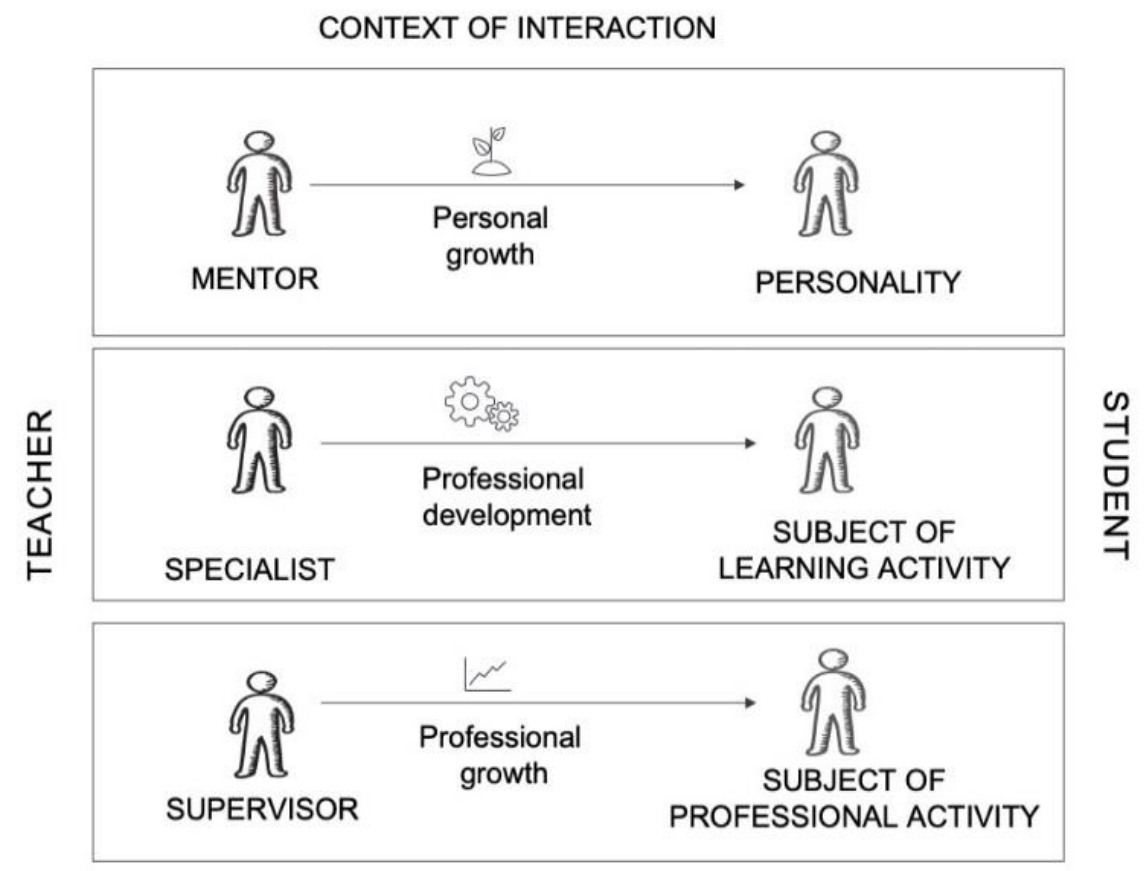

Regarding professional education process student could be considered as:

i) a personality (including individual experience, personal features and characteristics, aims, values and aspirations beyond learning process);

ii) a subject of learning activity (specifics of the student's intentional cognitive processes, learning goals and knowledge through professional training);

iii) a subject of future professional activity (the student's own reflection as a potential expert in a certain professional field; the development of professional knowledge and its structures: the concepts of professional practice, its tasks and technologies, etc.)

The role of university teacher therefore includes such positions as:

i) a mentor, who deals with student's personal growth, strengthening individual selfawareness, adequate self-assessment, assertiveness and cognitive interest reinforcement;

ii) a specialist, aimed on setting professional tasks, providing relevant methods and technologies and create professional-oriented learning environment; activity.

iii) a supervisor / expert, who performs assessment and feedback on the student's

Activity-based education therefore focuses on the specific content and goals of a particular professional practice, as well as related social and personal conditions of professional development. Furthermore, the implementation of activity-based learning includes a detailed analysis of the essence, intent and structure of the whole practice.

From the perspective of Activity theory social work may be defined as three levels of activity organization:

i) The level of ultimate values and principles, which establish certain quality and professional standards, governing all types of activities. 
ii) The level of norms and objectives, that determine major content and essence of professional interaction.

iii) The level of professional interaction, which includes social worker's interpersonal contact with a client and other professional matters.

Each level requires specific personal-professional skills that abstract knowledge could not cover (Fig.3).

Figure (3): The structure of social work activity

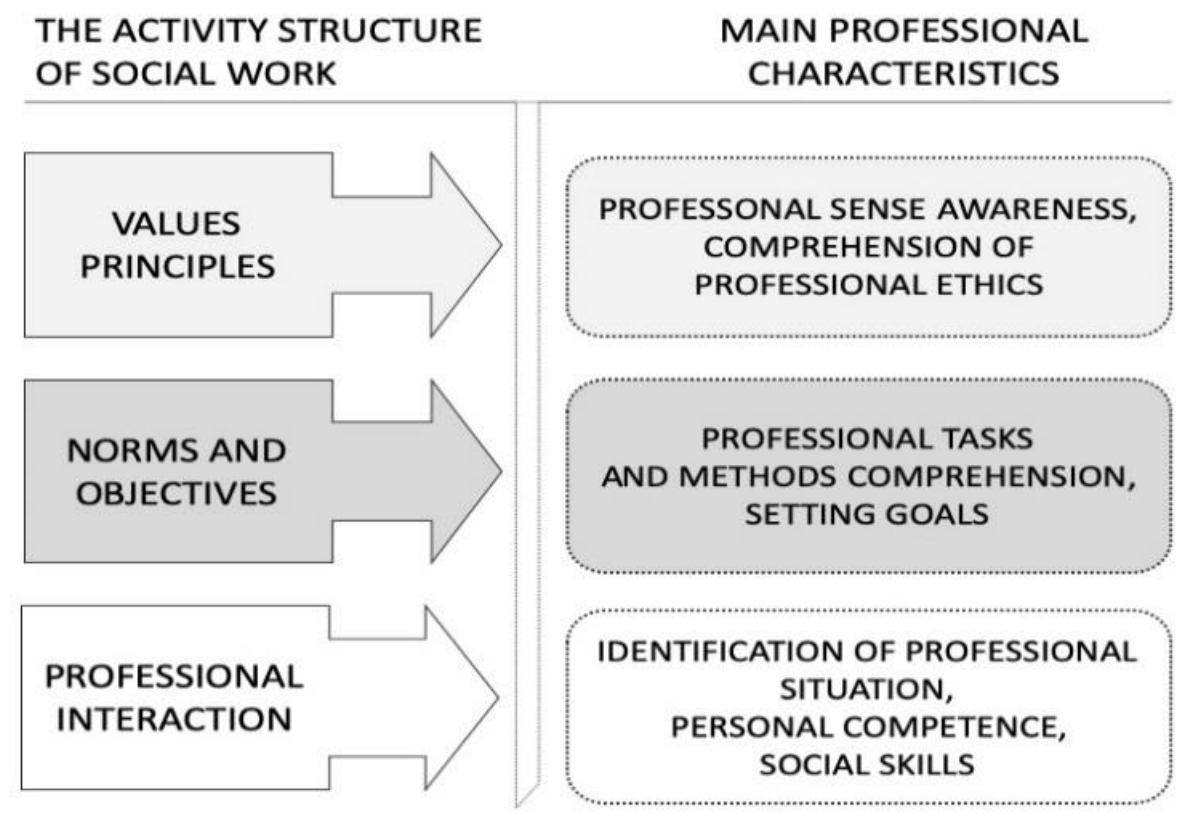

As a practical matter, there are difficulties associated with factors, including such, at the level of specific interpersonal interactions: contrasting circumstances of social and professional life; personal issues relating to the need to interfere in the condition of the client's life without their consent; empathy and compassion, etc.

Contradictions arise for the level of normative activity regulation (the level of principles and norms) due to the presence of heterogeneous and various professional standards and regulations that can sometimes be inconsistent with each other. Consequently, the circumstances of professional activity constantly require from social worker to make personal decisions in the process of setting the activity's professional tasks and enforcing rules of contact with the client and his social environment.

On the level of ultimate values and goals, the main challenge of social workers' professional practice would be the discrepancy between the declared principles and the general goals of social work and the actual possibilities of realistic activity for their implementation (Kuntsevska, 2004).

In the situation of solving a professional task, the decision taken should never be spontaneous, emotional, unreasoned, otherwise it becomes an objective barrier that hinders its solution. The youthful age of maximalism, stubbornness, unbalance, and judgmental superficiality can become an obstacle that buffers the ability to understand the essence of professional inquiry. 
In this regard, it is essential to provide specific conditions through which students personal growth becomes the matter of special "nurturing", which requires performing particular pedagogical methods and designing relevant practices (Chuiko, 2013, p. 182). This means to build environment where learning becomes meaningful, and students approach awareness of goals of professional activity, self-planning and self-control strategies that reflect personal maturity.

\section{Results and Discussion}

Considering today's challenges, Department of Social Rehabilitation and Social Pedagogy (Taras Shevchenko National University of Kyiv) has been currently implementing educational technologies that involve bachelor and master students in professional-oriented social practices.

Activity-oriented educational practices offered to students, contain the core components of their future professional activities. There are certain patterns in the logic of their implementation and student participation: all of them demand competence in project design and concern different aspects of social work.

Professional-oriented practice is a kind of independent students training in a specially structured professional environment aimed on discovering and approving professional forms of action, fully realizing the internal (concealed) specifics of professional activity, as a condition of gaining personal experience in the future profession.

Professional practice comprises a broad range of subjects ' interactions; enables students to accumulate experience in obtaining the essential forms of professional activity, mastering professional norms and role models, accumulation of personal results and achievements, and the experience of representing them at different levels.

Activity-based learning philosophy and, in particular, professional-oriented practice aimed at developing students ' personal maturity in the field of social work and embodied in the set of following principles:

- Participation of students in relevant educational practices under the supervision of departmental professors;

- Presentation of the findings of the student academic work experience, social projects, social events, etc.;

- Roughly equivalent use of individual, team and institutional learning methods, implementation of educational coaching technologies to promote and sustain the learner improvement trajectory;

- Considering students, teachers and employers ' professional and personal needs;

- Independence and active role of students;

- Prevalence of co-operation in professional tasks.

Among the various types of professional-oriented practices in social work education, we have established such general types as: volunteer activities, research, social project design, organizational and management.

Volunteer professional-oriented practices. The primary goal of engaging social work students in volunteering is to develop practical capabilities relevant to interpersonal emotional 
experience. These are the individual formations that make the helping process humanistic and meaningful, like empathetic support, sensitivity, acceptance, unbiased attitude, etc.

Volunteer activities encouraging students to participate in and initiate different forms of charitable activities, promotions and fundraising. Activities related to children's rights, school inclusion and social support projects for adolescents from orphanages and foster homes are the most common among "social pedagogy" students. Meanwhile, the prevailing "social rehabilitation" practices among students concerned juvenile probation, internally displaced persons and persons with disabilities.

According to L. Conway, there are several aspects of the volunteers' individual management: training, supervision, support, recognition and encouragement (Conway, 1994, p. 32).

We have distinguished 4 stages in the course of volunteer-oriented practices:

1. Introduction. At this stage, students acquire fundamental expertise concerning volunteer activities through specialized disciplines (for instance "Organization of volunteer activities"). Students Defining priorities and objectives together with an instructor in accordance with relevant social organizations ' concrete queries. It is important for students to find the personal significance of their planned activity. This stage concludes with an introductory conference in which freshmen students receive a volunteer memorandum detailing the roles, duties and obligations of the volunteers towards clients.

2. Practicum. A particular activity of the volunteer took place here with the supervisor's guidance, department's teachers and the service agency's specialists support. In their records, students keep accurate notes, chart the feedback from volunteer clients, their wishes.

3. Analytical. Students are gathering, interpreting and evaluating the findings as well as reflecting on the professional skills they have gained and developing them in the format of scientific work.

4. Control. Public defense of the student's course work takes place at this stage attended by the department's teaching staff, graduates of other classes, social service members, with official rewarding the best volunteers.

Interviews, performed this year among the first-year students $(n=25)$, participated in volunteer activities showed that the majority of them (92\%) perceive their experience of volunteering practices positively.

They mentioned that their view of the profession has evolved from personal contact with social work clients. Participants became more conscious of their motivation, ability to contribute and their awareness of social work. $85 \%$ of volunteers reported having gained practical work skills: dealing directly in a difficult situation; recognizing people's needs at a professional level; overcoming barriers of communicating with strangers; overcoming anxiety and shyness; being polite and friendly. In comparison, students from the control group who were not engaged in volunteering did not experience any changes in their attitudes (Chuiko, 2010).

Research professional-oriented practices. The peculiarity of the subject of study, which is directly related to the substance of social work professional activity, defines the nature of research procedure. This means that the main purpose of involving social work students in research practices is to acquire functional research skills as a common way of mastering reality 
and to enhance the personal stance of the student in the educational process by developing subjectively new, personally meaningful knowledge.

Research practice involves individual and team studies both within a specific discipline and in a master / bachelor paper. The principle of the collective-distributed model of activity, developed by V. Davidov and D. Elkonin, is applied in team research. Due to this, the student is strongly motivated to overcome the research tasks set.

In fact, interest become the main stimulus, which eliminates the problem of forced motivation and compulsory search in solving research problems through the mechanisms of meaningfulness and emotional involvement.

Furthermore, this way of organizing the activity is the key to the formation of the social worker's important professional skills-teamwork and team decisions. The uniqueness of this style of profession-oriented research is its collectively organized mode of activity which includes cooperative student work in 4-5 participants micro-groups, established as a key principle of learning-development technology.

The classification of the social issues studied is as follows:

- The individual in society: oppression, exclusion, loneliness, social isolation, stigma.

- Socio-environmental issues related to the protection of the environment, contamination in major industrial centres, environmental disasters.

- Public socio-economic issues (including increasing of poverty).

- Individuals, groups, families and communities' behavioral deviations (aspects of deviant behavior, societal differences, drug addiction, obesity, psychological anomalies, etc.).

- Communication problems, information assistance.

- Problems of power structures that rely on social tension and unity in society, on the government (totalitarianism, democracy or authoritarianism) and social activity of the population.

The research subject implies the students ' independence and initiative, which can sometimes take on an unpredictable nature (for example, the need to play a skilled beggar's role in determining their needs). In this case, students interest in the subject of study guarantees their real involvement, which contributes to the formation of personal maturity in the professional training. Moreover, students acquire specific and personal abilities: interpersonal contact establishing, conflict prevention, interaction at different levels, etc. Research results are publicly represented in the format of a coursework (or a course project) and assessed by the Department committee.

Social project design considered to be a common practice for bachelors and aimed at improving their problem-solving skills, predicting social situations, raising awareness of limitations and professional self-assessment. Students demonstrate their ability to understand the problems of target groups and to gain experience of real social change. The mastery of social design technology encompasses seven levels, each of which is clearly defined in terms of time and material.

Stage I - Getting acquainted with the technology of social design within the discipline "Fundamentals of social design". 
Stage II - Gaining skills of distinguishing relevant social interests and personal resources of each group member, project team management and main goals of social projects by professional communication training.

Stage III - Writing a social project based on a SWOT analysis (identifying the strengths and weaknesses of the project, as well as the opportunities and threats arising from the external environment). Normally there are 3-5 project groups set up and each group is led by a departmental instructor who shares similar interests / or practices related disciplines in the project area.

Stage IV - Presentation of project ideas at the department. The core concepts of the project are explored at this stage, representing the curriculum produced in the expert setting of the department's teachers.

Stage V - Gaining external expertise through project proposals to grant organizations (e.g. British Council). Project teams receive funding for the project in the case of positive feedback.

Stage VI - Implementation of the project. A social project's duration is determined by objectives, resource availability, characteristics of potential consumer behavior. It usually takes 3-4 months to complete.

Stage VII - Report of the project and its completion. The quantitative and qualitative parameters established earlier are used to evaluate the effectiveness of the project. Comparison of the intended and actual outcomes of the project determines the efficacy of the conducted activities and allows to make pertinent adjustments of the project, which is also presented in the report.

The analysis of the implemented projects demonstrates relevant students competencies, including: ability to empower young leaders; skills for social situation examining (interview and survey performing); mastering learning methods (lectures, conversations, training, practical classes, video lectures); counseling (individual, group); ability to conduct group activities; development and support of information resources: websites, social network pages, etc.; mastering community work methods: performance, street actions, civic actions, social theater technologies; organizing and maintaining support groups; performing leisure and recreational activities: children's camps, winter and summer schools; development, discussion and lobbying of legislative acts.

Organizational and Management practices. The main goal is to train the social worker as a manager capable of managing processes of social development aimed at ensuring citizens ' social well-being. This type of practice takes place in the bachelor's and master's courses and includes the systematic implementation of the skills acquired in previous years: psychological, legal, project, pedagogical, exploratory, that enables students to carry out high-quality academic research.

Graduation work must include a practical component and should fully reflect independent study experience in order to address a specific social issue covered by management skills; including following: to be able to set up social contacts; be able to consciously apply information and communication technology to professional practices, to consider its perspectives and outcomes; to form an interdisciplinary team; to build and implement social programs and social projects; be able to apply social services methods; to be able to use innovative technologies (social partnership, social consultation, social innovation, social entrepreneurship, etc.). 
Thus, the involvement of students in organizational and management practices allows the process of professional preparation to be systematic and complete:

i) as a result of the personal involvement of students in the content of future professional activities;

ii) by establishing a professional position, the core of which is social activity, aimed on social environment transforming according to the objectives set;

iii) training skills obtained through performing different types of professional activities.

Table 1 displays the characteristics of basic and additional professional-oriented activities that occur during university studies. Such practices are learned through the involvement of students in the related types of activities, which accumulate professional significance and practical content.

Accordingly, each of these practices involves a number of professional tasks, the solution of which generates specific personal capacities that constitute the foundation of the professional's personal maturity.

Table (1): Types of professional-oriented practices

\begin{tabular}{|c|c|c|c|}
\hline $\begin{array}{l}\text { Types of } \\
\text { professional-oriented } \\
\text { practices }\end{array}$ & $\begin{array}{l}\text { Types of activities } \\
\text { that students learn }\end{array}$ & Professional tasks & Personal capacities \\
\hline \multicolumn{4}{|l|}{ GENERAL } \\
\hline Volunteer activities & $\begin{array}{l}\text { Promotions } \\
\text { Charitable activities } \\
\text { Fundraising }\end{array}$ & $\begin{array}{l}\text { Involvement in } \\
\text { supporting various } \\
\text { groups of disabled } \\
\text { persons and groups }\end{array}$ & $\begin{array}{l}\text { Psycho- emotional self- } \\
\text { control } \\
\text { Impartiality } \\
\text { Professional empathy }\end{array}$ \\
\hline Research & $\begin{array}{l}\text { Observation } \\
\text { Diagnostics } \\
\text { Monitoring } \\
\text { Expert assessment }\end{array}$ & $\begin{array}{l}\text { Analysis of the } \\
\text { peculiarities of life of } \\
\text { different social groups } \\
\text { and strata, of social } \\
\text { status, of mental and } \\
\text { social well-being, of a } \\
\text { particular socio-cultural } \\
\text { space }\end{array}$ & $\begin{array}{l}\text { Research tasks setting } \\
\text { Conducting research } \\
\text { procedures } \\
\text { Analysis of social problems } \\
\text { Working in research teams }\end{array}$ \\
\hline Social Project Design & $\begin{array}{l}\text { Designing } \\
\text { Modeling } \\
\text { Prognostication } \\
\text { Project } \\
\text { implementation }\end{array}$ & $\begin{array}{l}\text { Designing } \\
\text { implementation of social } \\
\text { projects aimed at } \\
\text { changing of social } \\
\text { reality }\end{array}$ & $\begin{array}{l}\text { Predicting social situations } \\
\text { Awareness of limitations } \\
\text { Defining objectives } \\
\text { Reflection of actions }\end{array}$ \\
\hline $\begin{array}{l}\text { Organizational and } \\
\text { Management }\end{array}$ & $\begin{array}{l}\text { Organization of } \\
\text { professional groups } \\
\text { Team building } \\
\text { Leadership }\end{array}$ & $\begin{array}{l}\text { Finding ways to increase } \\
\text { the efficiency of social } \\
\text { services at the } \\
\text { individual, group, } \\
\text { family, community }\end{array}$ & $\begin{array}{l}\text { External positioning } \\
\text { Activation of resources } \\
\text { Decision-making } \\
\text { Targeting }\end{array}$ \\
\hline \multicolumn{4}{|l|}{ ADDITIONAL } \\
\hline Communicative & $\begin{array}{l}\text { Facilitation } \\
\text { Moderation } \\
\text { Mediation } \\
\text { Media } \\
\text { communication } \\
\end{array}$ & $\begin{array}{l}\text { Establishing } \\
\text { communication to } \\
\text { provide professional } \\
\text { assistance and support to } \\
\text { different categories and }\end{array}$ & $\begin{array}{l}\text { Establishing a contact } \\
\text { Preventing and resolving } \\
\text { conflict } \\
\text { Influencing } \\
\text { Detection of manipulations }\end{array}$ \\
\hline
\end{tabular}




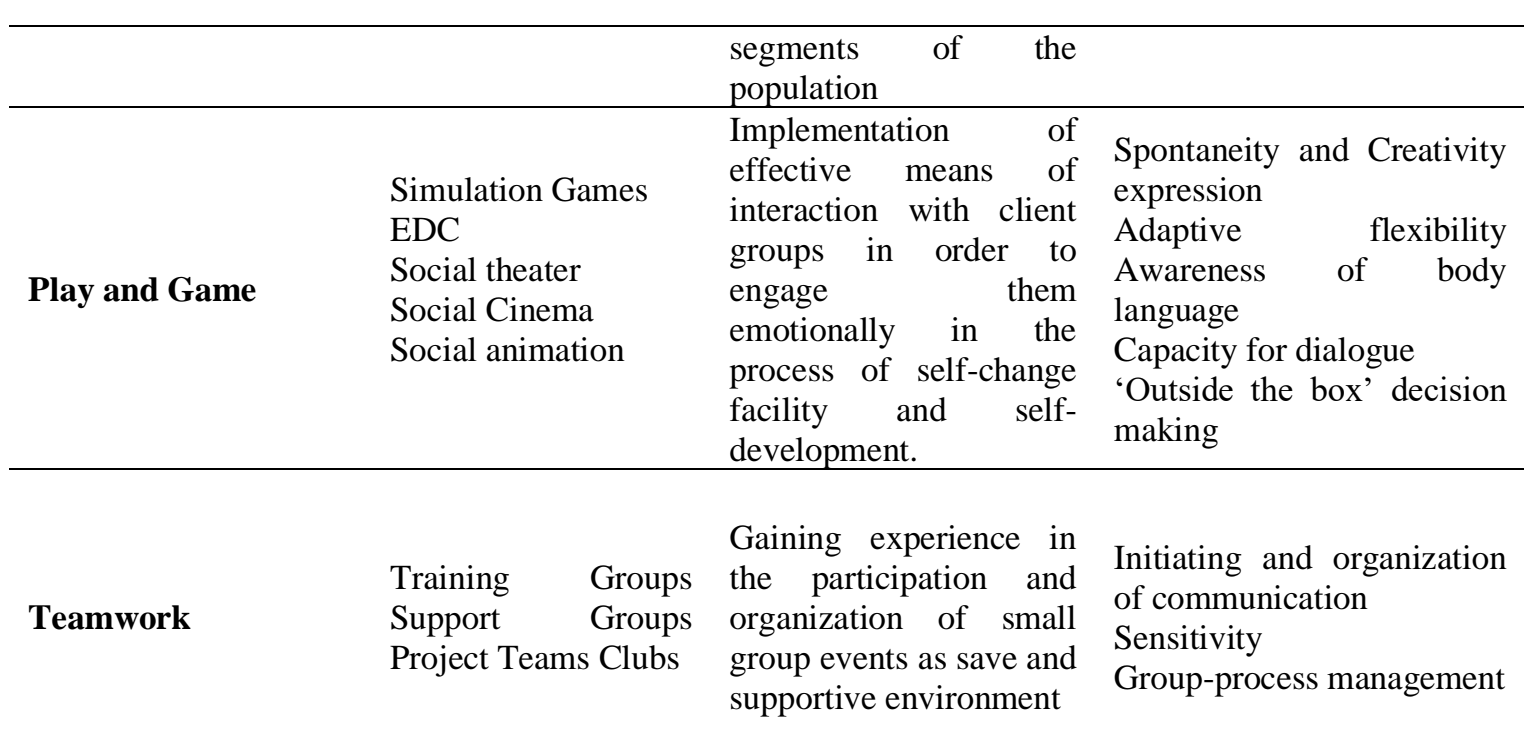

In addition to extracurricular practice students are involved in variety of professionaloriented educational activities including communicative, play and game practice, and teamwork activities, which based on professional content and address the academic and social needs of young people. These practices are called upon to broaden and enrich the set of student professional tools through the acquisition of personal experience of participation.

Communicative practices should be mentioned in particular, because they form the basis of social work activity. The social problem is a common subject of professional communication in the field of social work. However, every time constructing specific forms of communication, the subject is clarified, adjusted to determine the content of the main professional tasks of the social worker.

In practical social work, the following levels of professional communication can be differentiated by the positions of the subjects:

i) specialist - client (interaction between social worker and client, or group of clients);

ii) specialist - specialist (interaction between specialists in the field of social work and liaison between social workers and representatives of other social institutions and organizations);

iii) client - client (support groups), and by the type of the subject: interpersonal, public, mass communication.

Consequently, distinct type of communication requires definite skills, for instance, public communication (conference speech, presentation of a social project etc.) takes place in accordance with certain rules - participants can only interact with each other in a given format, and the action itself occurs according to a specific scenario. Some of the professional communication skills could be learned in special curricula training, however, major communication competencies can only be obtained through professional experience.

The activity-based professional learning process includes several stages:

i) general introduction to the subject of training and task setting;

ii) students` involvement in the relevant activities: volunteer, research, social project design, or organizational and management, and the accomplishment of the tasks; 
iii) supervision and reflection on the process and outcomes of the practice;

iv) conceptualization of knowledge and skills acquired through professional / volunteer practice and setting new tasks.

Each stage requires a certain position and the relevant competencies of the teacher and student with regard to their objectives (Fig.2). In the first stage, the teacher acts as a mentor, helping students to understand the demands of the practice In the second stage, the teacher acts as a specialist in order to support the successful involvement of students in their professional activities In the second stage, he acts as a supervisor, provides an assessment procedure and manages the process of reflection; he finally returns to the mentor position, helping students to accumulate personal experience and incorporate it further into professional expertise.

\section{Conclusions}

Recent studies had shown, that Ukrainian higher education in the field of Social work demand for a complete methodological upgrade of the content, methods and approaches. The majority of Ukrainian education programs are not practical-oriented, which lead to lack of competences of graduates, decreasing interest to the learning process and eventually have negative impact on social work practice. Activity paradigm in education regards education as a process of learning operations, which involves subject-oriented practical and mental actions. Activity-oriented education consists of key components of social work practice, require competence in project design and concern all aspects of social work.

From the perspective of Activity theory social work may be defined as three levels of activity organization: the level of ultimate values and principles, which establish certain quality and professional standards, governing all types of activities, the level of norms and objectives, that determine major content and essence of professional interaction; the level of professional interaction, which includes social worker's interpersonal contact with a client and other professional matters.

Each level needs special personal-professional skills that abstract knowledge cannot fully cover. That is why we develop activity-based approach, which aimed on filling the gap between theoretical knowledge and professional experience - the profession-oriented practice.

Profession-oriented practice includes general (volunteer activities, research, social project design, organizational and management) and additional (communicative, play and game, teamwork) forms and technologies, which demand from students to accumulate their experience in obtaining the essential forms of professional activities. Professional practice encompasses a set of principles, based on the prioritization of the social work profession, individual activity, participation and reflection, which make possible the development of the student's personal maturity and independence.

The involvement of students in professional activities can reduce the current lack of practical experience and train a socially mature and socially oriented graduate.

\section{References}

Bazhanov, V. (2009). The activity approach: Encyclopedia of Epistemology and Philosophy of Science. Moscow: Kanon+.

Chapaev, N., Akimova, O., Selivanov, A., Shaforostova, T. (2016). The Activity-Based Approach to Achieving Theoretical and Practical Consensus in Pedagogy of N. F. Talyzina Nikolay K. J. Env., 11: 8821-8833. 
Chuiko, O. (2010). The Motivation ready to master the profession, subject to analysis and form. J. Act. Prob.Psych., 7(24): 267-273.

Chuiko, O. (2013). Personal formation of subjects of professional activity in socionomic professions: monograph. Kyiv: ADEF-Ukraine.

Conway, L. (1994). Working with Volunteers: Support. London: Grate British.

Engestrom, Y. (1999). Perspectives on Activity Theory. Cambridge: Cambridge University Press.

Engestrom, Y. Expansive Learning at Work: toward an activity theoretical reconceptualization. Journal of Education and Work, 14(1), 133-156.

Gedera, D., Williams, P. (2016). Activity Theory in Education. Research and Practice. Sense Publishers - Springer.

Hansson, T. (2014). Contemporary Approaches to Activity Theory: Interdisciplinary Perspectives on Human Behavior: Interdisciplinary Perspectives on Human Behavior. IGI Global.

Kubitsky, S. (2017). Analysis of educational and professional training programs for specialists in the specialty 231 Social work. Pedagogical Education, 6.

Kuntsevska, A. (2004). Psychological models of intra-personal conflicts (to the problem of intra-personal conflicts in the activity of social workers). Bul. Soc. Ps. Ped., 20-21: 99-102.

Leontiev, A. (2001). What is an active approach in education. J. Elem.sch.E., 1: 3-6.

Lukashevich, M., Semigina, T., Cherepanova, G. (2007). Social Work (Theory and Practice): Textbook. Kyiv: IPK DSZU.

Maksakov, S. (2016). The main provisions of the theory of the activity approach in learning. Youth Scientific Forum: Humanities: electr. Sat Art. by mat. XL Int. Stud. Scientificpractical conf. No. 11(39). Retrieved from: https://nauchforum.ru/studconf/gum/xl

Manheim, K. (2000). Favorites. Sociology of culture. Moscow: University book.

Mishchik, L. (2016). Features of a systematic approach in the professional activity of social workers. Bull. Ped. Sc., 133. Retrieved from: http://nbuv.gov.ua/UJRN/VchdpuP_2016_133_37

Mitsi P., Papaspyrou, G. (2017). Implementation of "Activity Theory" in the framework of Differentiated Teaching: A Case Study. International Journal of Teaching \& Education, 2: 57-73.

Rubtsov, V. (2008). Socio-genetic psychology of developing education: an activity approach. Moscow: MHPPU.

Ryabova, Y. (2011). Preparing future social workers for professional work in a multinational environment: PhD Thesis Abstract. Kherson: Kherson State University.

Savelchuk, I. Training of Social Workers in Modern Conditions: Innovative Trends. Pedagogical Education, 1(83).

Savitskaya, V. (2015). Preparing future social workers for future activities on the basis of a praxeological approach. Rivne: National University.

Shvalb, Y. (2010). The system of vocational training of social workers: conceptual grounds for development. J.H.S, 5-6: 55-67.

Vasilyeva, M. (2011). Formation of professional reflection of future social workers in a classical university: PhD Thesis Abstract. Kiyv: National Pedagogical Dragomanov University.

Yamazumi, K. (2006). Activity Theory and the Transformation of Pedagogic Practice. Educational Studies in Japan: International Yearbook, 1: 77-90.

Yamazumi, K. (2006). Activity Theory and the Transformation of Pedagogic Practice. Educational Studies in Japan: International Yearbook, 1: 77-90. 